\title{
Study of Managerial Decision Making Linked to Operating and Financial Leverage
}

\author{
Dr. Syed Mohammad Faisal ${ }^{1}$, Dr Ahmad Khalid Khan ${ }^{1} \&$ Dr Omar Abdullah Al-Aboud ${ }^{1}$ \\ ${ }^{1}$ Assistant Professor, Department of Accounting, Faculty of Administrative Science, Jazan University, Jazan, KSA \\ Correspondence: Dr. Syed Mohammad Faisal, Assistant Professor, Department of Accounting, Faculty of \\ Administrative Science, Jazan University, Jazan, KSA
}

Received: October 3, 2017

Accepted: October 21, 2017

Online Published: December 4, 2017

doi:10.5430/afr.v7n1p139

URL: https://doi.org/10.5430/afr.v7n1p139

\begin{abstract}
In this paper, we as researchers try to quantify the effect of Operating Income or Earning Before Income and Taxes (EBIT) on individual listed firm on stock market and we study simultaneously the effects of Earning Per Share (EPS) on shareholder wealth.

Furthermore, we tried to build up hypothetically an optimal capital structure firm that uses an appropriate combination of Equity as well as Debt.

Rate of Interest and Tax are based on assumptions keeping in mind the present economic conditions of USA (assumed).

We have studied in detail about Operating and Financial Leverages and thus further explained Degree of Operating Leverage (DOOL) as well as Degree of Financial Leverage (DOFL).

In our study, initially we try to give a conceptual framework of the Leveraged Firm by taking hypothetical statistics and then in conclusion part Managerial Role and decision-making is discussed.

During our study, intense literature review and genuine hypothetical figures fitted to present economic conditions of Tax Rate and Interest Rates done in order to link with managerial decision making in levered companies.
\end{abstract}

Keywords: Operating Leverage, Financial Leverage, Combined Leverage, EBIT, EPS, Fixed Cost, Variable Cost, Net Income

\section{Introduction}

For any listed company concerned manager needs know the basic understanding of its capital structure and then know the effective and appropriate uses of debt and equity to establish balance capital structure in their Financing decision making approach. It is essential for them to know the operating income (EBIT) and its effects on Firm through the Operating Leverage and then to know EPS and its effects on shareholder wealth with changes in its value depending upon capital structure.

To explore more accurately, researchers have planned systematic study by setting some objective to draw conclusions about the topic.

\section{Objective}

- To draw a frame work of Operating and Financial Leverage

- To build up an optimal capital structure of Debt-Equity

- To forecast Managerial Decision Making in levered companies specifically Financial Leverage

- To enhance shareholder wealth through Financial Leverage

Managers need know the various types of Risks involved in studying Operating or Business as well as Financial Risks as mentioned below-

\section{Business Risk}

Companies are exposed to fall within business risk because of the effects of many confounding interrelated factors such as size of firm, competition in the market, sales volume, product design and diversification and more 
importantly Operating Leverage, that would be our part of the discussion in this paper, where variability in Operating Income (EBIT) affect firm substantially. To understand this concept we have Break Even Analysis that is important to know the effects of changes on Fixed Cost, Variable Cost, and Revenue.

We assume that firm has both fixed cost such as Rent, Salaries, Tax etc as well as Variable Costs such as labor costs, sales commission etc. More clearly see the figure as mentioned below-

\section{Break Even Analysis}

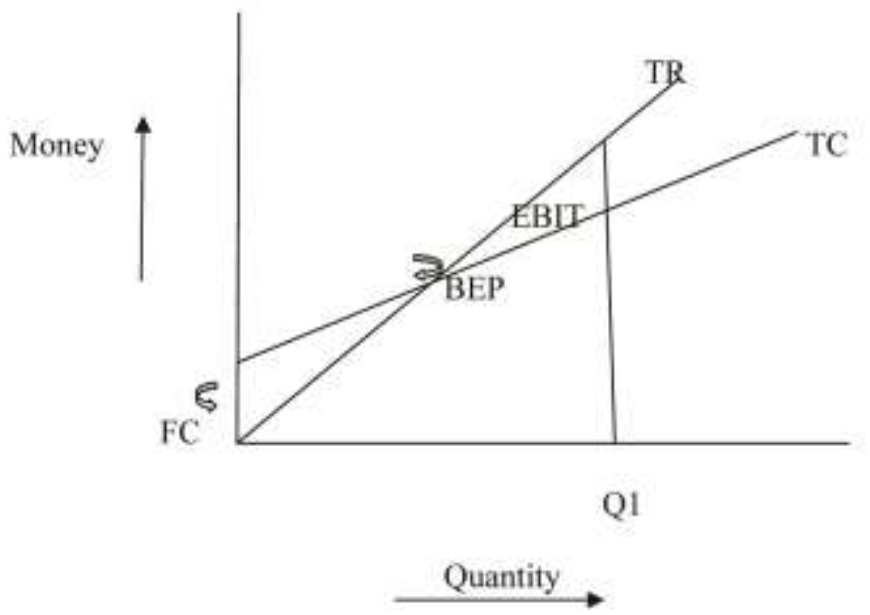

By this graph, it clearly shows that with an increase of sales quantity there will be higher operating income provided with the same level of fixed as well as variable cost.

In addition, if fixed costs are increased then firm must enhance its sales volume to meet out its fixed operating cost.

\section{Financial Risk}

Financial Risk is all about variability or uncertainty of company's Earnings Per Share (EPS). Financial Risk of any company also measures the risks associated with probable insolvency that may arise due usage of company's access financial advantage.

If a company is exposed to financial risk, its EPS gets poorly affected and thus resulted poor shareholders' wealth.

By previously mentioned definitions, it is found cleared that Business Risk is caused by Operating advantages that affects operating profit of the company, Earning Before Income and Taxes i.e. (EBIT) and Financial Risk is caused by Financial Leverages that affects Earning Per Share i.e. (EPS) that further leads poor Shareholders' wealth.

\section{Operating Leverage}

We shall first examine how operating profits i.e. EBIT gets affected by Operating Leverages through charts and thus analyze graphically Degree of Operating Leverage (DOL),

\section{DOL $=\%$ change in EBIT / \% change in Sales volume}

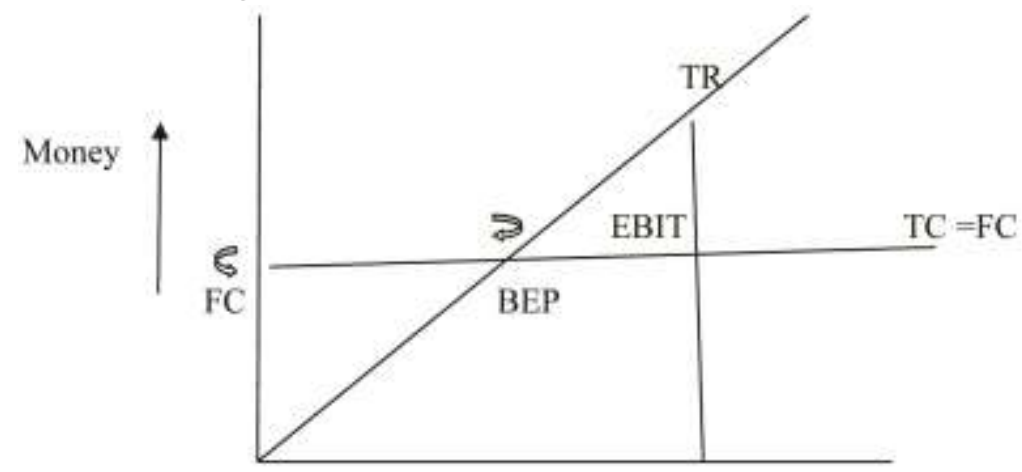

Q1

\section{Quantity}


It is evident from the graph that if there are increased in sales so there are higher operating profits no matter if fixed operating costs are high enough.

Also, it is evident from the graph, if operating costs are high or increased with no increased in sales volume than even Break Even Point will not meet, therefore all firms must analyze their balances of Operating Fixed Costs, Variable costs and their Sales Volume.

\section{Financial Leverage}

Financial Leverage or Gearing is best described by the capacity to use borrowed funds such fixed charges sources of funds like debt from financial institutions and preference capital along with owners' equity in the capital structure of any company.

The concept of Financial Leverages is to determine returns on fixed charges sources of funds or debts over their costs and thus interpret the performance of the company in the form of shareholder wealth.

The surplus over their cost will increase returns of owners' equity and vice versa.

To know more about impact of Financial Leverages we need to know Earning Per Share (EPS) Return on Equity (ROE) in details.

$$
\begin{aligned}
\text { EPS } & =\text { Profit After Taxes }(\text { PAT }) / \text { Total no. of shares outstanding } \\
& =\text { EBIT }- \text { Interest }(1-\text { T) } / \text { Total no. of shares outstanding } \\
\text { And ROE } & =\text { Profit After Taxes }(\text { PAT) } / \text { Value of Equity } \\
& =\text { EBIT- Interest }(1-T) / \text { Value of Equity }
\end{aligned}
$$

7. Financial Leverage and Its Impact on EPS and ROE with Constant EBIT in Two Different Capital Structure of a Firm

To ascertain an impact on EPS and ROE, we can assume two alternatives for a company with constant EBIT i.e. $\$ 150,000$.

In addition, we assume the capital structure of the company in the following manner.

- Capital structure $\$ 100,000$ where entire fund is raised through equity by issuing 10000 ordinary shares of face value $\$ 10$.

- Capital structure $\$ \mathbf{1 0 0 , 0 0 0}$ where $\mathbf{5 0 \%}$ fund i.e. $\$ \mathbf{5 0 , 0 0 0}$ rose through equity by issuing 5000 ordinary shares of face value of $\$ \mathbf{1 0}$. In addition, $\$ \mathbf{5 0 , 0 0 0}$ rose through debt with an interest rate

\begin{tabular}{|c|c|c|}
\hline \multicolumn{3}{|c|}{ Capital Structure of Firm with two alternatives } \\
\hline Financial Plan of Company & Debt-Equity (\$) & Only Equity (\$) \\
\hline $\begin{array}{l}\text { Earnings before Interest and } \\
\text { Taxes(EBIT) }\end{array}$ & 150,000 & 150,000 \\
\hline Less Interest i.e. $10 \%$ on $\$ 50,000$ & 5,000 & nil \\
\hline Earnings before taxes (EBT) & 145,000 & $\underline{150,000 * *}$ \\
\hline Less Taxes i.e. $50 \%$ & 72,500 & 75,000 \\
\hline Profit after Taxes (PAT) & 72,500 & $\underline{75,000 * *}$ \\
\hline Total earnings of investors & $\underline{77,500 * *}$ & 75,000 \\
\hline \multicolumn{3}{|l|}{ i.e. PAT + interest } \\
\hline No of ordinary shares outstanding & 5,000 & 10,000 \\
\hline $\mathrm{EPS}=\mathrm{PAT} /$ no of shares outstanding & $\underline{14.5 * *}$ & 7.5 \\
\hline $\mathrm{ROE}=\mathrm{PAT} /$ value of shares & $145 \% * *$ & $75 \%$ \\
\hline
\end{tabular}
(assumed) of $10 \%$.

In addition, we further assume 50 \% Tax rate to ascertain the impact on EPS and ROE in the given two different capital structures of firms in the following table. 


\section{Conclusion}

In our study, we researchers have found role and significance of Leverages both Operating as well as Financial in any sound company with proper objectives of profits for themselves and profits in the form of shareholders' wealth.

We first observed in our study that with some changes made in the Fixed Costs how Earnings Before Interest and Taxes get affected.

In addition, we examined various types of Business Risks involved in Operating Leverage in determining Break Even Point (BEP) graphically and thus variations in EBIT. As we increase in fixed operating cost with no increase in sales quantity then surely firm loses its operating profit because firm, then needs to make high efforts by reaching Break Even Point (BEP) or Cost Volume Profit (CVP). See the second graph.

Then researchers have shown in their analysis the part of Financial Leverage in which capital structure of the firm is assumed initially that it has only acquired sources of funds through equity by issuing ordinary shares amongst shareholders and in the second assumed part it has acquired 50\% of sources of funds through equity and rest part through debt from financial institutions.

It is clear from the above mentioned table that if a firm uses only equity that means without gearing or leverages then initially operating income i.e. EBIT increases and simultaneously its Profits after Taxes (PAT) to increases in that kind of Capital Structure of firm. However, total earning of investors remains same i. e. \$ 75,000; hence, EPS counted for this would be as shown in the above example will be 7.5

In another part when we study and analyze assumed capital structure of 50\% equity and 50\% debt, then it is found from above data that operating profits (EBIT) decreases, but Profits after Taxes (PAT) increases and thus the total earnings of investors from equity and debt also increases substantially that further leads to enhance share holders' wealth accordingly.

Same way firm's Return on Equity also increases substantially in mixed capital structure of the firm as analyzed from the above-mentioned table.

In our analysis of capital structure of firm having Equity as well as Debt in desired ratio is preferred in order to enhance the wealth of ordinary shareholders over firm having only equity or only debt in its capital structure.

\section{Scope of Further Study and Research}

This analysis is left to further study of other different kind or Risks involved in any business apart from Business Risk as well as Financial Risk to understand Operating and Financial Leverages along with further analysis of different companies in view of Operating and Financial Leverages.

Although apart from EPS, there are other many internal as well as external parameters to enhance the wealth of shareholders' wealth, which we have not considered in our study and made only EPS and ROE, two major financial parameters to ascertain the shareholders' wealth, therefore leaving for further study and research.

This further leaves to create hypothesis to buildup the optimal capital structure of firm depending upon size and requirements of funds during formation of the company and thus equity allotment by issuing ordinary shares and percentage of debts include in the capital structure of firm solely depend upon researchers for further scope of study and research.

\section{References}

Cevdet Aydemir Lehman Brothers Michael Gallmeyer. (2007). Financial Leverage and the Leverage Effect - A Market and Firm Analysis Texas A \& M University Burton Hollifield Carnegie Mellon University, burtonh@andrew.cmu.edu, Carnegie Mellon University Research Showcase @ CMU vol 3-2007.

Dr. D.Y. Patil. (2015). School of Management, Pune. International Journal of Research in Engineering and Social Sciences ISSN 2249-9482, Impact Factor: 5.343, 5(5), May 2015.

Dr. E. B. Khedkar Dean. (2007). Management Faculty, Savitribai Phule Pune University and Director, Financial Leverage and the Leverage Effect - A Market and Firm Analysis A. Cevdet Aydemir Lehman Brothers Michael Gallmeyer Texas A \& M University Burton Hollifield Carnegie Mellon University, burtonh@andrew.cmu.edu Research Showcase @ CMU Tepper School of Business 3-2007

Financial Leverage in Indian Pharmaceutical Industry. Asian Journal of Management Research. Online Open Access Publishing Platform for Management Research, 380 (2) (1). () Copyright 2010. Integrated Publishing Association. Research Article ISSN 2229 - 3795 
IlkkaKiema \& EsaJokivuolle. (2011). Bank Leverage ratio requirement, credit allocation and bank stability, Bank of Finland, Research Discussion papers, ISSN 1456-6184.

Nicoleta, Bărbuţă-Mişu. (2010). Financial Risk Analysis in the Building Sector: A Case Study of Romania (Galati County). ISSN 1392-1258. EKoNoMIKA. 89(1). Department of Finance and Economic Efficiency, "Dunărea de Jos" University of Galati, 9. Franklin, John and Muthusamy. K.S. (2011). Determinants of

Nissim \& Penman. (2003). Financial Statement Analysis of Leverage and How It Informs About Profitability and Price-to-Book Ratios. Review of Accounting Studies, 8, 531-560.

Shipra Gupta. (2012). Analysis of leverage ratio in selected Indian public sector and private sector banks. Asian Journal Of Management Research, 3(1), 2012, ISSN 2229 - 3795.

Tooba Raheel, Faiza Maqbool Shah. (2015). A Study That Identify the Relationship between the Financial Leverage and Firms Profitability: Empirical Evidence from Oil and Gas Companies of Pakistan Listed In KSE. International Journal of Scientific \& Engineering Research, 6(11), November-2015 80 ISSN 2229-5518.

Volume 2, Issue 5, May 2014 International Journal of Advance Research in Computer Science and Management Studies Research Article / Survey Paper / Case Study Available online at: www.ijarcsms.com An Empirical Study on Relationship between Leverage and Profitability in Bata India Limited Dr. M. Ramana Kumar.

Yuan, Y. (November 12, 2012). Impact of Leverage on Investment by Major Shareholders: Waseda Institute for Advanced Technology. 